\title{
Emotional Conflicts and Coping Strategies: The Case of Life Insurance Agents in China
}

SIXIN SHENG

\begin{abstract}
Through analysing Chinese life insurance agents' emotional conflicts and coping strategies, this study tries to reveal organization and work's impact on the agents. ${ }^{1}$ Because organizational and working rules are often inconsistent with social norms and personal feelings, life insurance agents easily experience negative emotions and conflicts. Various strategies that make efforts to solve this kind of conflict may trigger some new emotional problems and they probably make agents' emotional conflicts worse as well. In a way, emotional alienation has become a necessity for service workers in the post-industrial society and that means individuals' emotions and regulations are subject to the demand of organization and work, but deviate from egos and social rules.
\end{abstract}

Keywords: Life insurance agent, emotional labour, work, emotional alienation

\section{Background}

With the liberalization of the Chinese life insurance sector after 1978, the American International Assurance Company Limited (AIA) got into Mainland China and brought its system of life insurance agents in 1992. Later on, this American marketing model was introduced by Chinese life insurance companies because of its effectiveness, and soon became the dominant marketing approach in China's life insurance market. In the mid-1990s, Ping An (平安), a Chinese life insurance company, transformed the marketing model in more aggressive ways. Strategies used included the recruitment of large numbers of life insurance agents ${ }^{2}$ and a very strong control over the agents' minds and sales performance. To a large extent, these strategies had proved so effective that many other life insurers in China had to copy Ping An's strategies in order to compete in the market. One of the immediate results was that China's life insurance industry saw an overwhelming increase in the number of sales agents. From 1999 to 2005 the annual growth rate of Chinese life 
insurance agents was 30 percent. $^{3}$ Currently the national sales force in the Chinese life insurance industry is estimated at more than one million (Binder et al. 2005: 83-87).

The job of a Chinese life insurance agent is very tough. Although successful agents are very well paid, the majority experience low sales and emotional conflicts, leading to very high dropout rates. Only 20 percent of agents have worked in the life insurance industry for longer than three months. ${ }^{4}$ Moreover, Chinese society seems to give the profession little social respect. In a survey conducted by the Department of Sociology of Shenzhen University in 1999, among 100 kinds of professions in Shenzhen, the reputation of life insurance agents ranked $90^{\text {th }}$ (Guiru Li 2000), close to girls providing escort services (prostitutes). In another recent large-scale professional reputation survey conducted by Chunling $\mathrm{Li}$ (2005), the professional reputation of Chinese life insurance agents is also very low. There are at least three factors that contribute to the life insurance agents' low reputation. First, all life insurance agents are taught to adopt aggressive marketing techniques, such as badgering possible customers until they buy life insurance. These marketing techniques tend to annoy customers. Second, many life insurance agents often abuse interpersonal relationships during work. In some cases, they have even cheated those who have trusted them. Third, in order to get more agents, life insurers set a very low qualification requirement for entering the profession. At the same time, these companies do not attach much importance to the construction of agents' professionalism, focusing only on the agents' sales performance.

The low reputation of the profession also indicates that social resistance to life insurance agents is quite common in China. Thus, it is understandable that Chinese life insurance agents always experience negative emotions such as frustration because of rejections and contempt due to the low reputation of their profession. Based on a comprehensive study of life insurance agents in Xiamen, China in 2006 involving 20 interviews and a survey, this research investigated the emotional dimension of life insurance agents' work and discussed how various strategies are used to cope with emotional conflicts the agents encountered. This paper will argue that organization and work may lead to emotional alienation, and a new dimension of alienation should be proposed to complete Seeman's alienation concept (Seeman 1959, 1975). 


\section{Literature Review}

\section{Study of Emotions at Work}

The role of emotions in the workplace is important (Fox and Spector 2002). Ever since Hochschild (2003[1983]) identified emotions as a necessity in the work of air stewardesses, there have been abundant studies of emotions in other professions, focusing on an emotional management perspective. More researchers recognized the importance of emotions in work (Fisher and Ashkanasy 2000; Lord and Kanfer 2002). Earlier, Hochschild formally introduced the concept of emotional work into sociology. This term refers to 'the act of evoking or shaping, as well as suppressing, feeling in oneself' (Hochschild 1979: 561). Following the study done by Hochschild, one notable paradigm regarding emotional analysis in the workplace has been emerging in recent theories (Hochschild 1979, 2003[1983]; Wharton 1993; Morris and Feldman 1996; Fineman 2000; Lord et al. 2002; Diefendorff and Gosserand 2003) and empirical studies about the emotional labour in professions such as call centre workers (Deery and Kinnie 2002; Callaghan and Thompson 2002; Korczynski 2003), sales agents (Martin et al. 1998) and frontline service agents (Ashforth and Tomiuk 2000). The main themes included in this paradigm are emotional labour process, emotional rules and conflict, emotional management/ control, gender difference and inequality, and job burnout (Maslach et al. 2001) or other consequences caused by work.

However, in the case of life insurance agents, their work is slightly different from the emotional labour existing in the other service sectors. Compared to the latter, where service providers are always waiting for potential customers to approach them, the life insurance industry relies instead on their agents' efforts to explore potential customers and persuade them to buy the service. During the process, life insurance agents often experience negative emotions for various reasons such as frequent rejections and lack of social respect. Thus the agents have to deal with these situations to survive in the industry and life insurance companies also try to help them maintain morale through various ways. In that sense, Brotheridge and Grandey's typology about emotional labour may be helpful for defining life insurance agents' work. Brotheridge and Grandey (2002: 18) argued that there are two kinds of emotional labour: 'employee-focused emotional labour' and 'job-focused emotional labour'. The former refers to the 'employee process or experience of managing emotions and expressions to meet work demands', while the 
latter denotes those service jobs that require frequent interactions with customers with a high level of emotional demands (such as air stewardesses and call centre workers). Apparently, life insurance agents' work falls into the category of 'employee-focused emotional labour'.

According to Hochschild (1979, 2003[1983]), emotional labour involves two processes: surface acting and deep acting (also see Zapf 2002). The former means that employees try to manage their outer emotional expression at work; the latter refers to one kind of effort or an in-depth process that tries to adjust/change internal thoughts and emotions to be consistent with the outer emotional expressions regulated by organizational display rules. China's life insurance agents are required to focus more on deep acting but less on surface acting. For example, one of the most important dogmas in life insurance companies is 'embedding insurance into life, embedding life into insurance' (保险生活化, 生活保 险化), which emphasizes agents' full devotion to the life insurance business. That cannot be achieved without life insurance agents' deep acting, especially because the job is tough and often brings frustrations. From the standpoint of life insurers, it is important to teach new agents the necessary skills to sell life insurance (generally associated with surface acting), but the crucial thing is changing the agents' negative experience and opinions on the job to positive ones (generally associated with deep acting). The latter is the key to maintaining life insurance agents and improving their productivity.

Turner and Stets $(2005,2006)$ summarized five sociological perspectives on studies of human emotions: (1) dramaturgical theories, (2) symbolic interactionist theories, (3) interaction ritual theories, (4) powerstatus theories and (5) exchange theories. ${ }^{5}$ To study life insurance agents and their work, all five theoretical perspectives are useful in terms of providing better understandings and explanations. Turner and Stets (2006) also identified two kinds of strategy that are often used in coping with emotions at work: behavioural strategy and cognitive strategy. They pointed out that in different theories on emotions, the behavioural strategy and the cognitive strategy have different contents and formats. Stets and Tsushima (2001) found that the actors' identities influenced their coping strategies towards emotions. For example, in the worker role (role-based identity), people use behavioural strategies more and in family (group-based identity), people use expressive and cognitive strategies more. This behaviour-cognitive strategies framework will be applied to the analysis of agents' coping strategies to various emotional conflicts. 


\section{Existing Studies on Life Insurance Agents}

Partly because the occupation of life insurance agent has a very short history, ${ }^{6}$ studies of life insurance agents are not abundant in post-reform China. Table 1 shows that there were only 92 academic papers concerning life insurance agents published in Chinese academic journals from 1994 to 2006. These articles focused mainly on issues such as governance and supervision of life insurance agents, reports of successful agents, system buildup and revisions, juristic issues related to life insurance agents, and life insurers' management of agents. In most cases, Chinese scholars took life insurance agents as a management or juristic topic and no studies threw light on life insurance agents' work and emotions from sociological perspectives. Although life insurance and sales agents have penetrated into the Chinese economic transition and people's daily lives, few of China's sociologists show interest in the topic of life insurance agents.

TABLE 1: Academic Papers Concerning Life Insurance Agents in China Journal Full-text Database, ${ }^{7}$ 1994-2006

\begin{tabular}{|l|c|c|}
\hline The Focus of Articles concerning Life Insurance Agents & $\begin{array}{c}\text { Number } \\
\text { of Such } \\
\text { Articles }\end{array}$ & $\begin{array}{c}\text { Percent } \\
\text { of Total }\end{array}$ \\
\hline Governance and supervision (outer) & 18 & 19.6 \\
\hline Reports of successful agents & 17 & 18.5 \\
\hline System buildup and revisions & 13 & 14.1 \\
\hline Related juristic issues & 11 & 12.0 \\
\hline Training, assessment and prompting (inner management) & 10 & 10.9 \\
\hline Agents and life insurance market & 7 & 7.6 \\
\hline Moral hazard, obligation and honesty issues & 7 & 7.6 \\
\hline Existing problems and solutions & 7 & 7.6 \\
\hline Foreign experience and situation & 2 & 2.1 \\
\hline Total & 92 & 100 \\
\hline
\end{tabular}

In the United States the profession of life insurance agent has been developed for about two centuries (Stalson 1942; Zelizer 1983: 17-25) and academic effort focusing on life insurance agents from sociological perspectives has produced remarkable results. Some studies provide us with the means to make a comparative study between American and Chinese life insurance agents. For example, Robin Leidner (1993) observed the work of life insurance agents in America. She found the life insurers used various emotional training programs to help the agents deal with frustration caused by the high rejection rate. Also, in order to work effectively, the agents give the company free rein in 
reforming them. In addition, Guy Oakes (1990a) also discussed the situation of the sales agents' exploitation of friendship for commercial purposes. He assessed that 'the sales process debases friendships it employs by translating them into commercial relationships' (p. 107). Indeed, one can find similar cases or situations in the Chinese life insurance industry, although there might be some subtle differences to the extent.

A number of western sociologists focused instead on institutional dilemmas embedded in the phenomenon of life insurance agents and their work. Biǵgart (1989) analysed the work's influence on life insurance agents' family and social relationships. Oakes (1990b) argued that the bad reputation of agents reflected some ethical contradictions in late capitalism. Indeed, agents have to deal with the dilemma between making sales (self interest) and providing service (customer benefit). This dilemma may be relieved to some extent but cannot be resolved through efforts made by insurers and the agents. In addition, Zelizer (1978) also pointed out that life insurance agents faced an institutional dilemma between commercialism and altruism, and this dilemma resulted in the low occupational prestige of the agents.

Another significant study that focused on Chinese life insurance agents was done by Chan (2004). In 'Making Insurance a Way of Life in China', Chan used a cultural sociological framework to explain the phenomenon of the emerging life insurance market in China. In another paper, based on the situation of life insurance agents in Shanghai, Chan (2007) implied that the institutional dilemmas of commercial life insurance (such as Zelizer's (1978) commercialism-altruism dilemma) caused the agents' 'ideological work', referring to the desired psychological attitude that is conducive to sales productivity.

Although the aforementioned research noticed life insurance agents' dilemmas and difficulties in their work, few studies had a detailed analysis of the emotional aspect of life insurance agents' work. In addition, few of them studied how life insurance agents deal with these dilemmas and difficulties. In particular, this study addresses the following questions: In China's social and economic transition context, how and why do organization and work bring life insurance agents emotional conflicts? How do life insurance agents deal with these emotional conflicts? Are their coping strategies effective? Based on the answers to these questions, this paper will resort to alienation theories and try to reveal the consequences resulting from emotional labour. 


\section{Four Major Situations Causing Emotional Conflicts}

Generally, there are two different kinds of emotions: positive and negative. For example, in Goleman's (1995) typology of emotions, anger, sadness, shame and disgust fall into the category of negative emotions, while love and happiness are positive emotions. For various reasons, life insurance agents often experience negative emotions such as anxiety, disappointment, frustration, awkwardness, anger and even shame. Life insurance companies identify these negative emotions as counterproductive forces and thus try to change agents' cognitions and infuse agents with positive emotions. As a result, the sharp contrast between negative emotional experience and positive emotional requirement often leads to the agents' emotional conflicts. Basically, emotional conflict means that individuals lose the consistent and harmonious experience of emotion because of different emotional arousals, which come from organizational and working rules on the one hand, and have something to do with social norms and personal cognitions on the other hand. In that sense, the emotional conflict of life insurance agents may support Merton's concept of sociological ambivalence, which 'refers to incompatible normative expectations of attitudes, beliefs, and behaviour assigned to a status or to a set of statuses in a society' (Merton 1976: 6). In the case of Chinese life insurance agents, there are four major situations in which the agents easily get involved in emotional conflicts: a large gap between expectations and realities, social resistance, commercialized use of guanxi networks and work-family conflict.

\section{Large Gap Between Expectations and Realities}

For new agents recruited, life insurance companies always try to arouse and firm up their passion for the profession through a series of trainings and rituals. In particular, senior agents in the company are invited to give new agents talks about their experience. Such talks aim to inspire new agents with possibilities of a prosperous future. The following is a good example:

I previously was a journalist in another city. One time, when I travelled to Xiamen, I met a life insurance agent on a bus, and she was very nice. Then she told me that the life insurance industry is very promising and asked me to join her team. Finally, I gave up my previous job and became a life insurance agent. When I made this decision, almost all of the persons around me thought I was crazy. However, after two years of hard work in this industry I bought an apartment and a car in this city already. Now you can see that my decision is wise, since my previous job could not give me so much. (Observation in May 2006) ${ }^{8}$ 
In addition, because the life insurance profession has a very low reputation, it is important to change the previous cognition of new agents acquired from the bad social evaluation of the life insurance business. As a senior manager pointed out,

Firstly, we try our best to recruit any possible persons as agent trainees and then brainwash them (gei tamen xi nao). This is the key. If the brainwashing is successful, the agent trainees will have the desired status and produce a good performance; if unsuccessful, the agent trainees will choose to quit. (Respondent \#1, June 2006) ${ }^{9}$

The main purpose of 'brainwashing' is to purge agents of any negative or inactive ideas in their minds and infuse them with aggressive and positive working attitudes. Besides the above storytelling, a range of 'brainwashing' measures is used to arouse life insurance agents' positive emotions toward their profession and work. These measures are consistent with interaction ritual theories' requirements for the arousal of positive emotion (Collins 2004): daily morning assembly in the life insurance company (individuals gathering in proximate space), morning body exercise with encouraging music (rhythmic synchronization of bodies), daily greetings and rhythmic applause among agents ${ }^{10}$ (mutual awareness and attention), sales trainings and experience exchanges (a common focus) and fraternal atmosphere ${ }^{11}$ (a shared emotional mood), etc.

As a result of these measures, new agents have higher expectations regarding their work. They expect that they will be successful in this industry and win other people's respect. However, after some time the discrepancy between expectation and reality easily makes agents experience emotional conflict.

My first days in life insurance companies were exciting, but after working for some time, what I heard from the company made me feel I was detaching from the real society, since many friends around me said that my life in the life insurance company was crazy and impractical, and they hoped I could be back to a normal life. ... Indeed, when I was in the workplace I felt good; but when I was back, I felt empty. ... I felt I was just living in the wealthy dream which was delineated by the company. (Respondent \#2, May 2006)

Initially, after I received the training, I thought it was an easy job for me, and I also believed that I could do very well. ... However, I found it is not as easy as my previous imagination, and people still resist the life insurance and agents. ... Yes, there may be some very rich agents, but I cannot see where they are, and most of us feel it is very difficult to be successful in this industry. ... I feel that the nice prospect described by the company is not real for us. (Respondent \#13, June 2006) 
The data from the quantitative survey ${ }^{12}$ reveal that 44.4 percent of agents said that their company's daily assembly did not make them feel happy, and 70 percent of agents felt that their company's training was not useful. Many agents (83.9 percent) reported that their enthusiasm for work was not as strong as their early working days in the industry.

Indeed, when life insurance agents' positive emotions are aroused by life insurance companies' 'brainwashing' measures, their expectations toward the profession are also elevated. Exchange theories on emotion identify expectation as a significant factor affecting emotional experience (Turner and Stets 2005, 2006). When agents' gains exceeded their expectations, they would experience positive emotions. Unfortunately, this is not always the case for most agents in reality. Because selling life insurance to Chinese people is a tough job, a more common situation is that agents' gains often fall below their expectations. Thus they easily experience negative emotions such as disappointment and stress. Obviously, the negative emotions experienced by the agents conflict with the positive emotions aroused by the life insurers.

\section{Social Resistance}

This research found that life insurance agents experienced various negative emotions when they encountered social resistance and lack of respect. Oakes (1990b) also found that life insurance agents in America had the same problem. This study identifies three forms of social resistance in which life insurance agents feel bad: frequent rejections, lack of social respect and intentional isolation.

\section{Frequent Rejections: ${ }^{13}$}

When I was an agent trainee, my mentor asked me to visit strangers in an apartment block (shaolou). I went door to door and asked if they needed life insurance. When I finished my task, my mentor asked me how many doors I knocked on. I told her the number was one hundred. And then she continued to ask me how many refusal cases I had. I replied, one hundred and one. There was another one, as I had refused myself, too. I thought I should change the job. (Respondent \#3, June 2006)

One day, when I asked a stranger to buy my life insurance, he promptly said yes to me without hesitation. But I only had this kind of luck once in a two-year working experience. ... Rejections always happen in our daily work. (Respondent \#13, July 2006) 


\section{Lack of Social Respect: ${ }^{14}$}

One day last month, I tried to persuade a housewife to buy my life insurance while her son was doing homework. She replied to my persuasion in this way: 'Do not disturb me, please! Now I need to help my son to study. If he cannot study well, then he has to sell life insurance in the future. That's not what I want!' ... On another occasion, I heard people say that 'if someone is a life insurance agent, then the agent's whole family will become shameless to disturb others' (yiren zuo baoxian, quanjia buyaolian). (Respondent \#4, May 2006)

Few customers refused us in a polite way. In many cases, the customer's attitude was very bad; and sometimes they even reviled us as cheats and rogues. (Respondent \#17, June 2006)

\section{Intentional Isolation: ${ }^{15}$}

When we went to some office buildings to look for business, we could always see the sign 'No Life Insurance Sales Agents!' (xiejue baoxian tuixiaoyuan). ... One time, I met an office lady at a classmate's wedding, and I wanted to become her friend (not for business). However, after we exchanged our business cards after the banquet, she said to me directly: 'Oh, sorry, I would not like to make friends with life insurance agents, please do not call me in future.' Then I felt very frustrated. (Respondent \#5, July 2006)

After becoming a life insurance agent, I gradually found many friends purposely kept away from me. ... Although I always tried to approach them and express my sincerity, they still thought I was a troublemaker rather than a helper because of my profession. (Respondent \#9, June 2006)

More specifically, frequent rejections often bring agents frustration. According to the survey, when life insurance agents encountered rejection, 83.9 percent of them felt frustrated. In addition, frequent rejections also bring the agents stress because life insurance companies set monthly sales targets for them. ${ }^{16}$ As for lack of social respect, it is a denial of life insurance agents' self concept construed by life insurers and themselves, and thus the agents easily experience anxiety, awkwardness and even shame. As symbolic interactionist theories point out, people experience negative emotions, when their selves are not verified by others in a situation. For life insurance agents, the extreme of social resistance is intentional isolation, which most threatens their self-concept. The above two cases of intentional isolation also show a significant consequence to the agents, that is, their job already influences their ability to maintain existing social networks and even makes it difficult to make new friends. 
In multifarious forms of social resistance, life insurance agents are likely to find what they learned from life insurers is quite different from what they got from the work: life insurance companies alleged that agents could earn a lot of money, but rejections are too frequent to make most agents rich; agents were indoctrinated with the idea that their profession was respectable, but the relentless fact is that their job lacks social respect. A more unexpected consequence for them is the intentional isolation. In a deeper way, the positive emotional display rules prescribed by life insurers are inconsistent with the feeling rules defined by agents' real experience at work, so the agents feel emotional conflict because of the social resistance to them.

\section{Commercialized Use of Guanxi Networks}

As noted, the job of life insurance agents is not easy. To reduce rejections and improve sales performance, agents are taught to use their guanxi networks to sell life insurance. Indeed, guanxi (social networks) is very powerful in Chinese society. In life insurance companies' training, agents are encouraged to use their pre-existing relationships to sell life insurance. ${ }^{17}$ The trainers teach that everybody has many guanxi networks that can be used, such as relatives, classmates, friends and former colleagues. Furthermore, these networks can be extended, from relatives to relatives' friends and other guanxi networks (referral method ${ }^{18}$ ). Although selling life insurance within guanxi networks has been proven effective, many agents still experience awkwardness when they utilize their social networks to make the deal. Especially for new agents, most of them feel nervous and awkward when they confront the situation. As two agent trainees said,

Although my director always encouraged me, I would not like to sell life insurance to my friends, since I do not know how to speak with them. I do not think most of my friends have strong desires to purchase life insurance. If the friend refuses me directly or indirectly, both of us would feel awkward; if he or she decides to buy but just because we are friends, I would feel that I owe him or her. (Respondent \#7, May 2006)

Then I thought my uncle would buy life insurance from me, so I went to see him. After I introduced various life insurance schemes, he said to me, 'Sorry, now I really do not have money, so I can't help you at this moment.' I felt very awkward. (Respondent \#12, May 2006)

Low professional prestige also can make life insurance agents feel awkward when they sell life insurance within guanxi networks. One agent told me her experience as follows: 
After I presented various advantages and benefits, I asked my classmate if she had any questions about the life insurance plan I designed for her. My classmate said, 'Why do you choose to be a life insurance agent? You know, it is not a good job.' I felt very awkward, and did not know how to respond. (Respondent \#8, June 2006)

Thus life insurance companies have to persuade their agents to change their minds on using guanxi in transactions. The following lectures I heard in my participant observation are a good illustration:

In the life insurance industry, if you want to succeed, you must change your mind about guanxi (relationship), renqing (favour) and mianzi (face). For example, in the last three years I successfully sold life insurance to many people who are related to my brother-in-law, a senior official in a local university. However, he often complains that my success makes him feel in debt to those persons who have bought my life insurance. In other words, he thinks his friends or colleagues are helping me when they buy life insurance. However, I don't think so, and I can't think so, either. Why? Because if it is, how could I repay all customers' 'renqing' in the future? In fact, I was helping those people and teach them the importance and benefits of life insurance. Most people do not have knowledge about life insurance, so they need us to educate them. We are helping them, or at least we can say that it is a mutually beneficial practice. Since you have a good network, why not deploy it and help your friends and relatives? (Observation in May 2006)

If your friends or relatives do not buy life insurance but encounter a bad accident one day, then you will feel very regretful for not selling insurance to them before. ... If you do not sell life insurance to them, they will purchase life insurance from other agents sooner or later.... Life insurance is a good thing, and good things should be shared with friends first. (Observation in June 2006)

Even though the above justifications might help agents get out to some extent, they are not always effective for all life insurance agents. The survey shows that 50 percent of agents said that they felt awkward when selling life insurance to friends or relatives. Here it is useful to introduce dramaturgical theories on emotions to understand agents' emotional experience in this regard. The element of cultural script is central to dramaturgical theories' explanations: individuals experience negative emotions when their behaviour deviates from social rules construed by cultural script. In Chinese culture, exploiting friends or other types of social networks (guanxi) to earn money is viewed as improper and dirty, especially when this behaviour happens regularly. ${ }^{19}$ However, due to life insurance companies' sales targets, many agents have to resort to this 'dirty' behaviour. As a result, previous relationships 
are easily spoiled by the commercialized use of guanxi networks, which brings agents emotional conflict. Oakes (1990a: 107) also pointed out in his study on American sales agents, 'agents who use friends as prospect violate their own friendships and debase the relation of friendship itself'. The following three cases provide support for the above argument.

In the past, every time I visited Xiamen, many of my friends and classmates would welcome me. However, when I came to this city to become a life insurance agent, the situation started to change. At first, they still came to my dormitory to visit me, but the frequency became less and less; and then it seemed that they would not like to see me anymore, since they were tired of talking with a life insurance agent. Finally, even when I did not want to sell life insurance to them, they still did not answer my phone calls. I felt so upset. (Respondent \#9, June 2006)

What makes me feel upset is I lost many friends after I joined in this industry. ... One time I said to a friend, 'If you are my friend, you should help me and buy some life insurance.' But he replied, 'That has nothing to do with friendship. I really do not want to buy this useless thing.' Then I felt very sad. After that, I never contacted him, and he also did not call me. (Respondent \#18, June 2006)

Many relatives who bought life insurance from me complained that I should not earn money from them, but actually I had given them some discount when they bought life insurance. ... I would never visit these relatives, and I also would not like to sell them life insurance. (Respondent \#11, June 2006)

The main reason for the above consequence is that 'commercialization destroys crucial social bonds' (Zelizer 1983: 91) that encourage non-business altruism and purely personal communication. As Durkheim (1964: 227-29) emphasized, any instrumental and commercialized imagination of social networks will hurt the bond that makes people live together.

\section{Work-Family Conflict}

In modern society, work-family conflict is quite common in lots of professions, and this issue is particularly serious to many life insurance agents. That largely results from the working ideology 'embedding insurance into life, embedding life into insurance', because it requires agents' full devotion to the life insurance business. In the fieldwork of this study, for example, many female agents complained that their husbands did not support their work, as their workday is too long to look after their families. When I interviewed one agent, her son complained:

I find my mother has changed a lot after doing the life insurance business. She comes back very late every day and is always outside. Even on the weekend, 
she is still busy with her business. She spends little time on accompanying me, and does not cook for me and my father anymore. I feel that, although she was quite concerned about me and my father in the past, now she cares about her life insurance business more. One time, my father went to another city, and then I had a fever at home. I called my mom for help, but she told me that she was very busy and could not come home immediately. In her eyes, her business is more important than me. (Respondent \#1, June 2006)

Because life insurance agents' professional prestige is very low, it is difficult for them to get their family members' support and positive evaluation. In some cases, life insurance agents' work also influences communication with their spouses, and thus their daily lives are affected. As one life insurance agent's husband said to me:

I feel very terrible. My wife always asks my friends and relatives to buy her company's life insurance, but most of them do not have much interest. However, my wife still keeps asking them to buy, and thus she offends my friends and relatives. As a result, when I call my friends or relatives to ask them to go out for entertainment, they always doubt me and think that I am helping my wife to sell life insurance. I tried to persuade my wife to give up selling life insurance to them, but my words did not work. Now I feel very shamed for her work in front of my friends and relatives, and we often quarrel for this. (Respondent \#10, June 2006)

In addition, for some new life insurance agents, their team manager often encourages them to buy life insurance for themselves or families. In fact, almost all life insurance agents, including some experienced agents (team manager or department manager), did so. There are three explanations for this behaviour. First, because agents cannot always reach the sales target, sometimes they use their own money to buy life insurance to fill the sales gap. Second, agents have received various training regarding life insurance, and hence they generally have a stronger insurance consciousness. Third, life insurance companies still offer the commission when agents sell insurance to themselves or their families. However, buying life insurance often costs a lot of money, so the agents' family members may have different opinions, especially when agents just want to reach the sales target while their families actually do not have the financial resources to buy insurance. Furthermore, some agents' family members do not regard life insurance as necessary. As a result, disputes between agents and their family members easily occur.

My husband scolded me and told me that I am very stupid, because I used our own money to buy some life insurance policies and also prepaid some insurance premium for some relatives' policies. Yes, our family is not rich, 
but I just want to use our own money to earn more money.... If I did not do so, I could not finish my sales target. (Respondent \#11, June 2006)

Because women are supposed to take more of the responsibility for looking after the family, they generally experience more work-family conflict than men. The survey result reveals that 53.4 percent of female agents reported work-family conflict while 41.3 percent of male agents did so. Power-status theories on emotion can provide a further elucidation to the work-family conflict. According to power-status theories, individuals experience positive emotions when they have power (status) or gain power (status), and vice versa. Life insurance agents have to work hard to survive in the industry, but their rewards are not necessarily proportional to their efforts. For many female agents who are not so successful in the profession, they easily lose their power (status) in the family because their devotion to life insurance does not generate enough economic contribution in lieu of their supposed roles in non-economic family affairs. What is worse, as the above cases indicated, family members may also complain that an agent's work negatively affects the family's social reputation and financial planning. For male agents who get married, if they cannot earn the money expected to support the family, their power and status in the family will surely decline. As a result, agents experience negative emotions such as anxiety, fear, shame, embarrassment and loss of confidence. Meanwhile, they also feel unfairly treated as their efforts do not get the expected power and status from the family. Due to the different emotional experience aroused by life insurers' demands and by agents' power-status situation in the family, the work-family conflict also brings life insurance agents emotional conflict. Indeed, it is difficult for agents to find a trade-off point between work and family.

\section{Summary}

For the profession, emotional conflicts have three structural sources. The first structural source is related to the incompatibility between 'self perception and positive mindset infused by life insurers' and the 'low occupational prestige and social resistance' experienced by the agents. Life insurers always try to persuade the agents to believe that their work contributes significantly to the society's stability and they are engaging in a noble-minded profession. Yet, the fact remains that the life insurance agents' professional reputation is still quite low in society, and the agents easily encounter social resistance.

The second structural source lies in the contradiction between utilitarian guanxi networks and emotional guanxi networks. When life insur- 
ance agents continually utilize their guanxi network to sell life insurance, their guanxi network will not be functional in terms of providing emotional support as before, because the agents' personal relationships have gradually become purely business relationships. In other words, overly using guanxi in selling life insurance will weaken the foundation of guanxi networks.

Finally, life insurance agents' emotional conflict has something to do with the ideology of 'embedding insurance into daily life; embedding daily life into insurance', which blurs the boundary between work and personal life. It seems that life insurance agents have a great degree of job autonomy, because they are allowed to do whatever they want after daily morning assembly. The only task required of them is to achieve the sales target. However, the job is quite tough and life insurance agents are unable to control their job performance because of market uncertainties. Thus they have to spend most of their time developing business relationships or looking for business opportunities. As a result, the boundary between work and personal life is easily blurred. Many agents who cannot succeed but still stay in the industry experience a work-family dilemma that leads to agents' emotional conflicts.

\section{Behaviour and Cognitive Coping Strategies}

When life insurance agents experience emotional conflicts, they attempt to cope with the conflicts through various strategies. According to a useful framework developed by Thoits (1990), this paper divides agents' coping strategies into two different categories: behavioural strategies and cognitive strategies. Behavioural strategies 'involve acting or avoiding some aspects of the emotional experience', while cognitive strategies 'focus on changing the meaning of the situation' (Stets and Turner 2006: 125).

\section{Behavioural Coping Strategies}

This study finds that the behavioural coping strategies life insurance agents used include hiding the profession, teamwork and collective activities, consumption behaviour, and developing new networks and creating a good public image.

\section{Hiding the Profession}

One simple and common behavioural strategy used by some new agents is hiding their profession in front of some people who might be 
unhappy with it and criticize or belittle their job. Before people joined this industry, almost all of them assumed that life insurance agents did not have a good reputation. To avoid awkwardness or losing face, they would prefer not to let other people (even family members) know their occupation.

I do not even tell my husband what I am doing now. I know he won't support my work as a life insurance agent, since my job will put him to shame. ... When other people ask me why I go to the life insurance company, I just say that I want to buy life insurance, so I go to the company to have a look. (Respondent \#12, May 2006)

When some of my relatives asked me, 'What are you doing in the city?' I always told them I am working for a financial institution. ... I would not like to tell them I am a life insurance agent, since most of them think that is the last choice for those people who cannot survive in the city. (Respondent \#18, June 2006)

Actually, my parents do not support my work as a life insurance agent. They do not think it is a good job. ... I do not tell them what I am doing now, because I do not want to let them down. (Respondent \#3, June 2006)

The respondent \#18 is a non-local agent, so he could hide his profession better from relatives in his hometown. In this sense, this strategy has some positive implications for coping with agents' emotional conflict. However, for local agents such as respondent \#12, this strategy does not help much, and sometimes it worsens the situation. When they hide their profession, they live in fear that other people will know their occupation someday. The strategy is also difficult to make work with for a long time, because agents probably have to use pre-existing relationships to survive in the life insurance industry. Hence people around the agents will know their profession sooner or later.

\section{Teamwork and Collective Activities}

Teamwork and collective activities with colleagues is one important strategy to deal with emotional conflicts. As discussed earlier, life insurance agents often encounter social resistance, and they are also gradually alienated from their previous guanxi networks by their occupation. Thus it is difficult for agents to get emotional support either from outside or within pre-existing relationships. As a result, they resort to their colleagues who do the same work and have the same experience. For some new life insurance agents, when they feel awkward for selling life insurance to some people, they may ask their colleagues to work together. Indeed, when agents face problems or emotional con- 
flicts, their colleagues can help them and provide emotional support to some extent.

I cannot imagine how I could survive in this industry without some colleagues' help. During my first three months as a life insurance agent, almost all my family members and relatives were against me, but my colleagues and directors always encouraged me, and gave me a hand when I felt frustration. (Respondent \#11, June 2006)

Then I wanted to sell life insurance to one relative, but I did not know how to explain various insurance terms. I was also stressed and worried that the deal was unsuccessful. Finally, one experienced colleague helped me. ... That was my first policy sold. (Respondent \#14, June 2006)

The above argument is also supported by the data collected in the survey: 67.8 percent of agents said their director was responsible, and always helped them in work; 81.3 percent of agents thought their colleagues were very friendly; and 76.3 percent of agents agreed that they often helped each other when someone had difficulty. These numbers reveal the importance of a work team and colleagues for life insurance agents.

In addition, participating in various collective activities organized by the company is also important for relieving emotional conflicts. Generally, this kind of activity is often related to physical exercise and amusement (such as mountain climbing, bicycle riding, going for a picnic and playing games). These activities provide the agents communication opportunities to release their emotional tension.

To sum up, the strategy of teamwork and collective activities emphasizes the essentiality of colleagues in their work and lives. The reason, as Hochschild (1997: 282) pointed out, is 'friends at work play an important role in emotional support'. When staying with their working friends, life insurance agents feel more comfortable, because their common emotional experience allows them to bond together.

\section{Consumption Behaviour}

Another significant behaviour in coping strategies is consumption. In most cases it takes the form of materialistic consumption. During the fieldwork I found that many agents use this strategy very often, especially when they close a big deal.

You know, the work is not easy. ... Every time when I got a big policy I would have a dinner with some colleagues to celebrate and then go shopping. ... I do not think I should treat myself too bad and I should enjoy my life. (Respondent \#13, June 2006) 
In effect, life insurance companies also provide agents some incentives to consume. For example, in some marketing competitions organized by life insurers, the winners generally are awarded opportunities to travel. Although life insurance agents could cash in the tourism opportunities, most winners still chose to go travelling to relax.

Last year I got an opportunity to go to Vietnam for tourism. Because of my excellent sales performance, the company even allowed my child and husband to go to Vietnam with me. That was our first time abroad. ... When I stood in Vietnam I felt very proud of myself. I thought all my efforts paid to the life insurance business are worthwhile.... We were very happy, and the tour left the whole family with a very sweet memory. (Respondent \#14, June 2006)

For China, economic reform also brings transition from a producer society to a consumer society, in which consumption 'makes and maintains social relationship' (Douglas and Isherwood 1979: 60). In general, consumption behaviour relieves life insurance agents' emotional conflicts in two ways. First, as respondent \#14 reveals, intentional consumption behaviour is changing the life insurance agents' role from a service provider to a customer in the market. The enjoyment and satisfaction brought by this kind of change may transfer or alleviate their emotional conflicts at work. Second, through consumption, life insurance agents can provide their families with necessities, such as buying food, clothes and a house, or even a more decent and comfortable life achieved by buying electric appliances and a car. This point can also be used as a good justification for life insurance agents' work and the 'dirty money' they earn.

As Bourdieu (1984[1979]) pointed out, people use different consumption patterns to express or demonstrate their social status in society. Indeed, consumption highlights life insurance agents' other relatively higher social roles (such as parents and consumers) and obscures their low status as life insurance agents. However, compared with the role as a consumer, life insurance agents' working role is more common in their daily life, since their working time is very long as I discussed before. In addition, consumption requires money, but most life insurance agents are unable to afford the cost of 'distinguished' or frequent consumption that could help them to deal with emotional conflicts. Thus one can see that this behaviour strategy's effectiveness is short-lived and has its limitations.

\section{Developing New Networks and Creating a Good Public Image}

For life insurance agents, the most sophisticated behavioural strategy is developing new networks and creating a good public image. Chan (2003), in her study on life insurance agents in Shanghai, found that 
some agents did not sell life insurance to their relatives and good friends in order to protect these relationships, and they explored business opportunities among nodding aquaintances or developed friendships with potential customers. Other research on direct-selling salesmen in Taiwan also revealed that weak ties rather than strong ties play a more important role in expanding a market network (Lan 2002). This study also found that some senior agents adopt a similar strategy: they try to develop new networks through helping others.

Once one of my potential customers was sick and I visited her in hospital almost every night. I looked after her and accompanied her to chat, but I never talked life insurance with her.... When she recovered after two months, she voluntarily proposed to buy insurance from me. She said I was a good person. (Respondent \#14, June 2006)

On that day a customer came to our company and wanted to extend his policy, but he did not know how to do it, because the agent who helped him in the past had left the company. Thus I helped him. He appreciated me very much, and then introduced some business to me. (Respondent \#16, June 2006)

The above two cases show the agents' efforts to develop weak ties with their potential customers. Then selling life insurance to these customers is free of emotional conflicts. To develop new networks, agents generally need to offer help to show their kindness to others, or else they cannot gain potential customers' appreciation and trust. In the survey, 92.3 percent of agents also claimed that they often helped other people who had difficulties. However, life insurance agents have to devote much time and emotion when using this strategy where they also need to hide their marketing intention. However, their customers' responses are hard to predict, and public opinion is difficult to change through some life insurance agents' effort during a short time. Thus their effort does not guarantee the expected return.

In addition, life insurers and their agents have attached some importance to creating a good public image in order to reduce social resistance and improve their professional reputation. For example, some life insurance agents register in some non-government organizations as volunteers and contribute to social welfare. Sometimes life insurance companies also organize this type of activity with their agents. Besides this organized effort, some agents act independently and spontaneously to help the public in their own ways. Two of the respondents said:

Many people think life insurance agents are very selfish and materialistic. I do not think so. ... If I find some garbage on the road, I throw it into the 
garbage bin. ... Whenever I go by bus, I always offer my seat to elders or pregnant women. (Respondent \#15, June 2006)

I participated in some volunteer programs in some communities and helped some disabled or old people. The feeling of helping customers and that of helping the underclass are different. I felt very good when I could help those disabled persons or the elderly. This reminds me that my situation is at least better than them, and I should not complain. (Respondent \#17, July 2006)

Indeed, life insurance agents want to fight their bad reputation and show the public a positive image. In a way, one can regard this behavioural strategy as an attempt to achieve a balance between market and culture. When agents earn money from the market, doing something good may wash away the cultural 'stain' brought by their profession. In this case, it seems that there is an exchange relationship between agents and their potential customers. In other words, when life insurance agents sell life insurance to their clients, they are regarded as receivers rather than providers from a cultural perspective. When life insurance agents are doing something good, they are seen as providers. Both Chinese culture and western market ethic emphasize that receiving should be based on giving; otherwise, the exchange relationship will be destroyed.

In summary, the above four behavioural strategies are commonly found in life insurance agents' work and lives. Unfortunately, deploying these behavioural strategies may trigger other emotional problems as well, for example, hiding the profession often brings life insurance agents stress. In most cases, the effectiveness of behavioural strategies is just situational and temporary. Perhaps the most effective strategy is simply to quit the industry and that is what many life insurance agents choose to do. Thus it is not surprising to see a high dropout rate in the profession.

\section{Cognitive Coping Strategies}

Compared with behavioural strategies, cognitive coping strategies are regarded as more influential for actors, the influence more sustaining (Stets and Turner 2006). This study proposes a broad definition of cognitive strategy, that is, social actors define situations or things in a manner that could aid them in dealing with emotional conflicts. Based on this definition, the main cognitive strategies used by life insurance agents in China fall into two categories: the first is ' $A h Q$ ' spirit (moral victory); and the second category has three sub-types that are based on life insurance agents' different understandings of their work. They are: pragmatism, idealism and exchange theory. 


\section{Ah Q Spirit (Moral Victory)}

Lu Xun (1881-1936), author and philosopher in China, created a famous figure, 'Ah $Q$ ', in one of his novels (The True Story of $A h Q$ ). He pointed out that the Ah Q spirit was one common aspect embedded in Chinese personality (Lu 2002). In the case of Chinese life insurance agents, this $\mathrm{Ah} \mathrm{Q}$ spirit is often used as 'moral victory' to relieve their emotional conflicts. In practice, there are three different forms for using Ah Q spirit: transforming external negative stimulations into positive self-evaluation, debasing the sources of negative stimulations and exaggerating related or unrelated positive stimulations.

Transforming external negative stimulations.

Many people say that life insurance agents are shameless, but I think this kind of shamelessness reflects our professionalism. Even though many people do not understand our work and always refuse us, we still try to help them. That reflects our good personality. (Observation in June 2006)

Debasing the sources of negative stimulations.

Indeed, some people said, life insurance agents are shameless, or life insurance is cheating, but I really looked down upon these arrogant and ignorant people. They will pay for their arrogance and ignorance some day. (Respondent \#16, June 2006)

\section{Exaggerating positive stimulations.}

Selling life insurance can help me meet many successful people who may help me in my future career development. ... Many rich people come from the life insurance industry, and many successful people also have the experience as a life insurance agent. It is said, if you can stay in life insurance companies for some time, you can stay anywhere in the future. (Respondent \#17, July 2006)

Indeed, the Ah Q spirit is effective for coping with some emotional problems resulting from outside sources (such as frustration due to social resistance), since it can transform or debase some problems the agents encountered. When it came to coping with emotional problems in work, one senior agent said,

As a life insurance agent, you really need some 'Ah Q' spirit, since it is impossible for us to change the world and the society around us, but at least we can change our minds on them. (Respondent \#1, June 2006)

The survey shows that 66.2 percent of agents felt that they could change their moods when they experienced negative emotions and 71.3 percent of agents expressed that they could maintain a good mood when facing difficulties. In this sense, Chinese life insurance agents have good 
command of Ah Q spirit, and it is a common strategy used by agents to cope with emotional conflicts.

However, those emotional conflicts related to cultural factors (such as selling life insurance within guanxi networks) and personal reasons (such as work-family conflict) are difficult for agents to cope with using $\mathrm{Ah} Q \mathrm{Q}$ spirit. Although $\mathrm{Ah} \mathrm{Q}$ spirit is able to transform the external negative response, many people who use this strategy are unable to disregard inner negative reactions from close relationships. For example, when it comes to the emotional conflict related to guanxi networks and family, the three different forms of $\mathrm{Ah} Q \mathrm{Q}$ spirit cannot help agents, because if agents belittle their close friends or family members they inevitably experience emotional ambivalence. In addition, life insurance agents also have difficulties in transforming negative stimulations or exaggerating positive stimulation, because negative stimulations actually come from agents themselves, and it is also difficult to find any positive stimulation.

In a way, $A h \mathrm{Q}$ spirit is just a cognitive tactic that arises from direct negative stimulations. When the stimulations disappear, Ah Q spirit will also disappear, but emotional conflicts still remain.

\section{Pragmatism}

Being pragmatic is also a cognitive coping strategy. Pragmatism emphasizes the importance of material success in social life, and it measures all kinds of ethical issues according to the effectiveness of the behaviour. In the 1980s, pragmatism was used to justify China's economic reform. As Deng Xiaoping's Cat Theory said, 'It does not matter if it is a yellow cat or a black cat, as long as it catches mice' (Deng 1989: 305). ${ }^{20}$ Indeed, in Chinese economic reform, rationality and efficiency are supposed to be given highest consideration (Pieke 1995). For individuals, money, as Poggi (1993) argued, has become an institutional phenomenon dominating modern people's lives. As a result, for life insurance agents who follow the idea of pragmatism, how much money they can earn from the market is their sole consideration. They try to ignore the emotional conflicts experienced. In the survey, 61 percent of agents reported that they did not care about other people's views so much.

In particular, the idea of pragmatism is used as a justification for life insurance agents using guanxi networks to earn money. To some agents, money can be the mediation between personal cost and market revenue. In other words, for those agents who believe in pragmatism, 
commercialization of guanxi networks is 'acceptable'. Even though the agents may encounter social resistance or offend pre-existing friends when selling life insurance too aggressively, they would still like to try their best to earn money. As the following two agents said,

If you do not have money, you will not have friends. If I lose friends because of earning money from them, at least I can get some money, and then I can use the money to make new friends. (Respondent \#16, June 2006)

Money is the first important thing in the modern society. Poverty is the root of evil, and everything will be better if you become rich. (Respondent \#6, May 2006)

To a large extent, the pre-existing guanxi network is spoiled by the pursuit of pragmatism. And pragmatism might result in more emotional problems because of the decline of morality in personality. In some close relationships, such as family and kin relationships, rationality cannot totally replace emotionality. Agents still need emotional support from close relationships. In addition, the effectiveness of pragmatism is also doubtful, because only a limited number of life insurance agents can earn a lot of money from the industry. ${ }^{21}$ In the survey, only 21.6 percent of agents said they are satisfied with their income. Thus those life insurance agents who are pragmatists may encounter another dilemma. They may find that pragmatism is not effective enough in terms of earning money. In that case, what do they do?

\section{Idealism}

For some agents who have a stronger moral conviction, an alternate strategy to pragmatism is 'idealism'. Agents who adopt this strategy believe that the selling of life insurance is a form of altruistic behaviour, and thus they attach more importance to their work's contribution to other people or the society. These agents try to construct their value system according to their relationships with others. As the following life insurance agents said,

What drives me to join in this industry? Last year, my brother was hurt in a traffic accident, but he did not buy life insurance and then the family had to spend all of our savings on my brother's treatment. ... From then on, I felt life insurance is very important for the public, so I decided to join in this industry helping other people who refuse life insurance. (Respondent \#19, May 2006)

One day, I received a call from a good friend and he said over the phone: 'Hi, friend, I just lost one of my legs in an accident, and now I am still in the hospital.' I was so shocked and went to the hospital at once. When I saw him in the sickbed, I cried. I regretted that a few days ago, when I met him, I did 
not try my best to persuade him to buy life insurance. Now I understand, life insurance is not useless, and it is real love! (Observation in June 2006)

Do you know the story of Yuan Yiping, the most successful life insurance agent in Japan? He always considers his customers and thus he wins other people's trust and respect. ... We should behave like Yuan Yiping. (Respondent \#18, June 2006)

These life insurance agents can ignore many outside criticisms and cope with emotional conflicts better. However, in China's economic transition, idealism is not commonly found compared to pragmatism among life insurance agents. The survey found that only 3.8 percent of agents often cared about their work's contributions to the society. Another fact may partly explain idealism's unpopularity: Chinese life insurance companies only focus on middle-class and rich consumers. Many poor people in rural areas cannot afford the cost of buying life insurance, even though they need it very much. In this sense, idealism is illusory.

\section{Exchange Theory}

Another cognitive coping strategy is the exchange theory. This strategy views life insurance agents' work in terms of reciprocity. The relationships between life insurance agents and their clients are regarded as one kind of exchange. On the one hand, agents provide the service and earn money from their customers; on the other hand, the buyer can also get protection from accidents and diseases to some extent.

Indeed, we totally rely on the commissions from clients' policies, but I do not think we are exploiting our customers. ... We give our clients professional suggestions on how to prepare for future uncertainties and risks. ... It is an exchange relationship, just like other business behaviour in the market. (Respondent \#20, July 2006)

I admit that I can earn commission from selling life insurance, but the buyers also get the insurance coverage. Like employees in other service sectors, we provide a service. Why can't we charge for our service? We are not doing charity. (Respondent \#4, May 2006)

Reciprocity generally means that the exchange is equitable and the result is mutually beneficial (Stets and Turner 2006). In that sense, reciprocity would be helpful for resolving emotional conflicts, if (potential) customers shared the above exchange perspective with the agents. Unfortunately, in the case of the life insurance industry, most customers actually do not think they get much payoff from buying life insurance, 
and many of them even assume life insurance is useless. In addition, it is difficult to convince the clients that they can get a payoff from unexpected accidents. In reality, the compensation they get from life insurance companies cannot recover what they have lost in the accidents. For more clients who had bought non-refundable life insurance, they paid the premium but got nothing because no accident happened.

Regular reciprocal exchange reduces distrust and resistance between two parties. A high frequency of exchange can increase the inner cohesion between social actors (Lawler and Yoon 1998). But in most cases, the exchange between agents and their clients is a one-time event; the very high dropout rate in the industry also makes follow-up interactions difficult.

To sum up, reciprocity as one cognitive strategy has its weaknesses. It cannot give agents strong support when they face emotional conflicts.

\section{Summary}

This section discussed life insurance agents' behavioural and cognitive strategies. It is important to note that different agents may adopt different strategies, and different strategies can also be combined to cope with emotional conflicts. The boundary between behaviour strategy and cognitive strategy is not clear-cut as well, since behaviour is always related with cognition after all. For example, consumption as one kind of behaviour strategy is linked to pragmatism, which attaches much importance to the role of money in the society.

TABLE 2. Correlation Analysis between Self-Adjustment and Job Burnout/Job Satisfaction Scale ${ }^{22}$

\begin{tabular}{|l|c|c|}
\hline & Job burnout scale & Job satisfaction scale \\
\hline $\begin{array}{l}\text { Self-adjustment scale } \\
\text { (Pearson Correlation) }\end{array}$ & $.612(* *)$ & $.553\left({ }^{* *}\right)$ \\
\hline
\end{tabular}

** Correlation is significant at the 0.01 level (2-tailed).

Yet, every coping strategy has its limitations. Various coping strategies might help life insurance agents mitigate their emotional conflicts, but they also result in other emotional problems and the deviation from social norms. As a result, life insurance agents still remain alienated from the society and even alienated from themselves. In the survey, the consequence of emotional conflicts is measured by the job burnout scale. 
Table 2 shows that emotional conflicts will be more serious when life insurance agents do more emotional work to adjust themselves, though their job satisfaction may be improved under this situation.

\section{Conclusion}

Pettinger (2005: 39) argued that there is a tendency for modern work in which 'the strict division between work and non-work lives is unsustainable in the face of a blurring of boundaries', as work interferes deeply with personal lives. The case of life insurance agents in China makes a good footnote for Pettinger's argument. The most important source for the agents' dilemma lies in their work ideology 'embedding insurance into life, embedding life into insurance', which also helps agents survive in the industry. However, this work ideology results in the blurry boundary between work and life.

Unfortunately, the blurred boundary between work and life does not bring employees liberation from work as some scholars believed (Shershow 2005). On the contrary, life insurance agents' lives have become more firmly dictated by the demand of work and the organization. Life insurance companies always try very hard to infuse agents with positive emotions and aggressive minds toward the work. But in fact, life insurance agents experience strong negative emotions at both work and home in various situations. This kind of inconsistency leads to serious emotional conflicts. In order to cope with emotional conflicts, life insurance agents turn to various behavioural and cognitive strategies. However, all of these coping strategies are found to be limited in terms of their effectiveness and even make the situation worse.

As I discussed earlier, many life insurance agents also pay a heavy personal cost for their work. Their pre-existing guanxi networks are adversely affected by the aggressive exploitation of guanxi for business purposes. Social resistance and low professional prestige also create difficulties for life insurance agents constructing new (nonbusiness) relationships with other people. Finally, under the stress of sales targets set by life insurance companies, many agents have to spend too much time on work so that they do not have enough time to perform their expected role in the family, which results in the work-family conflict. These negative consequences largely arise from rationality's unlimited erosion into personal life and emotions, which further alienates agents from society and even themselves. 
This paper argues that Seeman's alienation theory (Seeman 1959, 1975) should be revised in view of the case of China's life insurance agents. Indeed, four of six dimensions in Seeman's alienation concept can be applied to the life insurance agents in China: normlessness (business means are not socially recognized), cultural estrangement (commercialized use of guanxi network spoils cultural rules), self-estrangement (an individual's unique personality is restrained by the work) and social isolation (social resistance). However, the other two dimensions, powerlessness and meaninglessness, are slightly different from life insurance agents' situations. Seeman's powerlessness means that individuals totally lose control over their work and labour process, but life insurance agents' work is flexible in terms of working time and working process. What the agents cannot control are their job performance and the emotional conflicts. As for the dimension of meaninglessness, life insurance agents are also not the case of 'unable to understand others and social things', and the key is that their views are influenced by life insurers and their work.

In addition, another new dimension, emotional alienation, should be proposed to describe organization and work's influence on life insurance agents. Here emotional alienation refers to the situation in which individuals' emotions and regulations are subject to the demand of organization and work, but deviate from egos and social rules. Hence, emotional alienation can be viewed as the consequence of irresolvable emotional conflicts. The fundamental reason for emotional alienation is that the basis for capitalist production and organization (i.e. rational choice theory) is totally different from the foundation of emotional work (i.e. feeling rules defined by social and cultural factors). Ironically, the most successful life insurance agents must effectively master 'emotional alienation', even though it brings heavy emotional costs and damages their interpersonal relationships and social acceptance. In a way, emotional alienation can also be seen as an inevitable result of a rapidly developing service industry in post-industrial society, and it reflects a trend in which the demands of commercial work penetrate into the emotional world of human beings. Employees thus have to change their previous social ethics and emotional rules to accommodate the work's requirements.

Compared with Marx's alienation theory (1963[1844]), which emphasizes the exploitative relationship between capitalists and workers in the industrial society, service industry's emotional management in the postindustrial era focuses more on controlling employees' emotions to get business profits. ${ }^{23}$ The Chinese life insurance industry is one case; other service industries in China's economic transition are following the emo- 
tional management philosophy. In that sense, organization and work have a tendency to become a strong force to dictate a human being's body and emotion. In connection with Durkheim's theory of anomie (Durkheim 1951, 1958), emotional alienation can be seen as one kind of anomie that 'afflicts people in certain occupational roles 'at its micro-level, and at its macro-level it influences 'individual's specific group memberships and affects their capacity to function as responsible members of society' (Marks 1974: 357). With reference to Weber's opinion (Weber 1947), emotional alienation also can be viewed as an inhuman consequence brought about by formal rationality in China's economic transition.

In the future, when Chinese people understand and accept life insurance more, and when life insurance agents become more professional, the agents' situation might be better. But for now the situation is as Ouchi described (quoted from Scott 2003: 330), 'In much the same manner that firms were able until recently to pollute the air and the water without paying the costs of using up these resources, they (firms) continue to be able to pollute our mental health with impunity'.

Sixin Sheng is a Ph.D. Candidate at the School of Organization and Management, University of New South Wales in Sydney (sixin.sheng@student.unsw.edu.au).

\section{NOTES}

1 This paper is mainly based on a master dissertation finished at the end of 2007 in the Department of Sociology, National University of Singapore. The author wants to express great appreciation to Dr Alexius A. Pereira and Associate Prof. Hing Ai Yun for their mentorship and help during writing the dissertation. The author also would like to thank the anonymous reviewers for helpful comments.

2 This is the so-called "human wave tactics" (人海战术) in Chinese life insurance sector. In its essence, human wave tactics emphasizes that the large number of agents is the key to the success in the market, so it requires life insurers to recruit agents from the society in various ways.

3 The number is from my calculation of the data of Chinese Insurance Yearbook from 2000 to 2006.

4 The number came from Chinese Insurance Yearbook, from 2000 to 2006.

5 According to Turner and Stets $(2005,2006)$, dramaturgical theories emphasize the importance of cultural scripts in the dramatic presentations and strategic actions that occur in some certain situations. Symbolic interactionist theories believe that self and identity are the central dynamics of emotional incentives. Interaction ritual theories assume that individuals always try to maximize and increase their emotional energy and cultural capital in situations. Power and status theories argue that power, status and expectation play significant roles in emotional arousal. Exchange theories regard individuals as rational beings that are affected by their rewards and costs in encounters. 
6 For a longer history of Chinese life insurance, please refer to the Insurance Institute of China et al. $(1998,2005)$.

7 China Journal Full-text Database (http://www.cnki.net/index.htm) is the biggest Chinese online academic resource in the world. It covers about 5,300 Chinese academic journals and includes over six million academic papers. I checked the website on 23 November 2006.

8 The fieldwork was conducted from May 2006 to October 2006. Methods of participant observation, in-depth interview, and survey were used in the research.

9 For the selection of respondents, purposive sampling method is used for assuring representative characteristics. Four respondents in each of the five companies I studied were chosen. Among all of the 20 interviewees, half of them were female and half were male; half of them were under 30 years old and half were above 30; eight interviewees received higher education while the remaining did not have a degree or diploma; around half of interviewees had worked in the life insurance industry for at least two years at the point of interview, while the other interviewees were less experienced.

10 In life insurance companies, applauses with certain rhythms are to express awareness, thanksgiving, encouragement, respect and other positive emotions.

11 For example, agents are required to help each other. The inner common address for all agents is 'partner' (huoban in Chinese), regardless of position, age and gender.

12 Multi-stage cluster sampling method was introduced into the survey, which was conducted in five life insurance companies of Xiamen. The number of questionnaires sent out was 250, and the number of returning effective questionnaires was 182. Thus the response rate was 72.8 percent.

13 The reason for frequent rejection, in most cases, is mainly because people do not think they have the need for life insurance. Because of the planned economy background prior to China's economic reform, Chinese people generally lack awareness of and interest in buying life insurance. In addition, the concept of life insurance also conflicts with some traditional beliefs in Chinese culture. For example, as Chan (2004) pointed out, most Chinese people believe that accidents are far away from them. Some people even believe that buying life insurance is a kind of bad omen. Hence, many people dislike life insurance agents' solicitations.

14 To some extent, lack of social respect is caused by life insurance agents' misconduct in the early years when China's life insurance market was still immature in the economic reform. It also partly arises from the fact that life insurance agents can get the commission from selling life insurance to friends. In Chinese culture, this kind of behaviour is deemed as improper. In addition, the low professional reputation also results in the lack of social respect.

15 Intentional isolation largely reflects a kind of fear or averseness towards many agents' endless and aggressive marketing. As the above case indicated, intentional isolation makes it difficult for life insurance agents to construct new relationships with strangers.

16 In the survey, only 26.3 percent of agents expressed that they felt little stress to reach the sales target set by the company. Actually, one important reason for the stress is because life insurance agents are unable to control their customers' timing of purchases, while the evaluation of sales performance is periodical.

17 Generally, life insurance companies teach their agents three ways to exploit guanxi networks, namely, directly selling life insurance within guanxi networks, asking existing guanxi to recommend new potential customers, and persuading friends, classmates and relatives to become their downline agents.

18 In general, life insurance companies' training would introduce various methods to their agents to attract prospective customers, such as the 'pre-existing relationship 
method' (Yuangu Fa), 'stranger visit method' (Mobai Fa), 'referral method' (Zhuanjieshao), 'spontaneous method' (Suiyuan Fa), etc. All of these methods encourage an aggressive marketing model. For a detailed introduction to the four methods mentioned, please see Chan 2004.

19 In many cases, under the pressure of sales targets, when life insurance agents talk to their friends, classmates or relatives, the main topic is always related to life insurance and the main incentive is just to get some business opportunities.

20 This translation comes from online source of People's Daily of China; please refer to the following website: http://english.peopledaily.com.cn/dengxp/vol1/text/a1400

21 In a way, this is a structural problem. Life insurance companies in China employ a pyramid structure to manage their agents. Only those senior agents who are on the top of the pyramid can earn a lot of money and a large part of their income actually comes from their downline agents who are at the lower position in the pyramid.

22 I incorporated a series of scales into the three scales from some similar studies regarding emotional labour (self-adjustment scale refers to Snyder and Gangestad 1986; job burnout scale refers to Sutton 1991; Morris and Feldman 1996; Maslach et al. 2001; job satisfaction scale refers to Clark 1998; Rose 2003). However, I made some changes to these scales according to the result of a pretest, the reality of the life insurance industry and suggestions from professionals. In its final version, every scale was in the form of a five-point Likert scale. For every point from 'never' to 'daily' or from 'totally disagree' to 'totally agree', a mark from 1 to 5 is scored correspondingly. Sum of the marks for all items in a scale constitutes the scale score, which indicates the level of self-adjustment, job burnout or job satisfaction.

23 Scott (2003: 328-29) also pointed out there is a critical transformation from the industrial society to the post-industrial society, i.e., from the passive working behavioural model to relatively active behavioural models such as the emotional working type in the service sector nowadays.

\section{REFERENCES}

Ashforth, Blake E. and M. A. Tomiuk 2000. 'Emotional Labour and Authenticity: View From Service Agents'. In S. Fineman (ed) Emotion in Organization (2nd edition). Thousand Oaks, CA: Sage 2000: 184-203.

Biǵǵart, Nicole Woolsey 1989. Charismatic Capitalism: Direct Selling Organizations in America. Chicago: University of Chicago Press.

Binder, Stephan, Tab Bowers and Winston Yung 2005. 'Selling Life Insurance to China'. The McKinsey Quarterly: China Today. Special Edition: 83-87.

Bourdieu, Pierre [1979]1984. Distinction: A Social Critique of the Judgment of Taste. London: Routledge \& Kegan Paul.

Brotheridge, Céleste M. and Alicia A. Grandey 2002. 'Emotional Labour and Burnout: Comparing Two Perspectives of People Work'. Journal of Vocational Behaviour 60: 17-39.

Callaghan, George and Paul Thompson 2002. 'We Recruit Attitude: The Selection and Shaping of Routine Call Centre Labour'. Journal of Management Studies 39: 233-54.

Chan, Cheris Shun-ching 2003. The Cultural Dimension of Social Embeddedness: Blending and Differentiating Personal and Business Relations in Life Insurance Transactions in China. Paper presented at the $98^{\text {th }}$ Annual Meeting of American Sociological Association, August 16-19.

- 2004. Making Insurance a Way of Life in China: How Culture Matters in Creating a Market. 
Ph.D. dissertation, Northwestern University.

- 2007. 'Honing Good Attitudes: Ideological Work on Insurance Sales Agents'. In Ching Kwan Lee (ed) Working in China: ethnographies of labor and workplace transformation. New York: Routledge.

Clark, A. E. 1998. 'Measures of Job Satisfaction: What Makes a Good Job? Evidence from OECD Countries'. In Labour Market and Social Policy: Occasional Paper No. 34. Paris: OECD.

Collins, R. 2004. Interaction Ritual Chains. Princeton, NJ: Princeton University Press.

Deery, Stephen and Nicholas Kinnie 2002. 'Call Centres and Beyond: A Thematic Evaluation'. Human Resource Management Journal 12(4): 3-13.

Deng, Xiaoping 1989. Selected Works of Deng Xiaoping: volume 1. Beijing: the People's Press.

Diefendorff, James M. and Robin H. Gosserand 2003. 'Understanding the Emotional Labour Process: A Control Theory Perspective'. Journal of Organizational Behaviour 24: 945-59.

Douglas, Mary and Baron Isherwood 1979. The World of Goods: Towards Anthropology of Consumption. London: Allen Lane.

Durkheim, Emile 1951. Suicide. Translated by John A. Spaulding and George Simpson. New York: Free Press.

- 1958. Professional Ethics and Civic Morals. Translated by Cornelia Brookfield. New York: Free Press.

- 1964. Division of Labor in Society. New York: Free Press.

Erickson, Rebecca J. and Christian Ritter 2001. 'Emotional Labour, Burnout, and Inauthenticity: Does Gender Matter'. Social Psychology Quarterly 64: 146-63.

Fineman, Stephen 2000. Emotion in Organizations. London; Thousand Oaks, CA: Sage.

Fisher, Cynthia D. and Neal M. Ashkanasy 2000. 'The Emerging Role of Emotions in Work Life: An Introduction'. Journal of Organizational Behaviour 21: 123-29.

Fox, Suzy and Paul E. Spector 2002. 'Editorial: Emotions in the Workplace, The Neglected Side of Organizational Life Introduction'. Human Resource Management Review 12: 167-71.

Goleman, D. 1995. Emotional Intelligence: Why It Can Matter More Than IQ. New York: Bantam Books.

Hochschild, Arlie Russell. 1979. 'Emotion Work, Feeling Rules, and Social Structure'. The American Journal of Sociology 85: 551-75.

- [1983]2003. The Managed Heart: Commercialization of Human Feeling. Berkeley, CA: University of California Press.

- 1997. The Time Bind: When Work Becomes Home and Home Becomes Work. New York: Henry Holt.

Insurance Institute of China and Editorial Committee of 'The History of Chinese Insurance' 1998. The History of Chinese Insurance. Beijing: China Financial Publishing House.

- and China Insurance News (ed) 2005. Bicentenary Chinese Insurance: 1805-2005 (Zhongguo Baoxianye Liangbainian). Beijing: Contemporary World Press.

Korczynski, M. 2003. 'Communities of Coping: Collective Emotional Labour in Service Work'. Organization 10: 55-79.

Lan, Pei-chia 2002. 'Networking Capitalism: Network Construction and Control Effects in Direct Selling'. The Sociological Quarterly 43(2): 165-84.

Lawler, Edward J. and Jeongkoo Yoon 1998. 'Network Structure and Emotions in Exchange Relations'. American Sociological Review 63: 871-94.

Leidner, Robin 1993. Fast food, Fast Talk: Service Work and the Routinization of Everyday 
Life. Berkeley: University of California Press.

Li, Chunling 2005. 'Prestige Stratification in Contemporary China' (Dangdai Zhongguo Shehui de Shengwang Fenceng). Sociological Study 2: 74-102.

Li, Guiru 2000. 'The Issue of Professional Prestige Rank in Shenzhen City' (Shenzhen Zhiye Shengwang Paihang Chulu). in Market News. Beijing. 23 April.

Lord, Robert G., Richard J. Klimoski and Ruth Kanfer 2002. Emotions in the Workplace: Understanding the Structure and Role of Emotions in Organizational Behaviour. San Francisco: Jossey-Bass.

Lu, Xun 2002. The True Story of Ah Q. Hong Kong: Chinese University Press.

Marks, Stephen R. 1974. 'Durkheim's Theory of Anomie'. The American Journal of Sociology 80(2): 329-63.

Martin, Joanne, Kathleen Knopoff and Chrisine Beckman 1998. 'An Alternative to Bureaucratic Impersonality and Emotional Labour: Bounded Emotionality at the Body Shop'. Administrative Science Quarterly 43: 429-69.

Marx, Karl 1963[1844]. Theories of Surplus-Value: Volume IV of Capital. Moscow: Progress Publishers.

Maslach, Christina, Wilmar B. Schaufeli and Michael P. Leiter 2001. 'Job Burnout'. Annual Review of Psychology 52: 397-422.

Merton, Robert K. 1976. Sociological Ambivalence and Other Essays. New York: Free Press.

Morris, J. A. and D. C. Feldman 1996. 'The Dimensions, Antecedents, and Consequences of Emotional Labour'. The Academy of Management Review 21: 986-1010.

Oakes, Guy 1990a. The Soul of the Salesman: The Moral Ethos of Personal Sales. Atlantic Highlands, NJ: Humanities Press International.

- 1990b. 'The American Life Insurance Salesman: A Secular Theodicy'. International Journal of Politics, Culture, and Society 4: 95-112.

Pettinger, Lynne 2005. A New Sociology of Work? Oxford: Blackwell.

Pieke, Frank N. 1995. 'Bureaucracy, Friends, and Money: The Growth of Capital Socialism in China'. Comparative Studies in Society and History 37: 494-518.

Poggi, Gianfranco 1993. Money and the Modern Mind: George Simmel's Philosophy of Money. Berkeley: University of California Press.

Rose, Michael 2003. 'Good Deal, Bad Deal? Job Satisfaction in Occupations'. Work Employment and Society 17: 503-30.

Scott, W. Richard 2003. Organizations: Rational, Natural, and Open Systems. Upper Saddle River, NJ: Prentice Hall.

Shershow, Scott Cutler 2005. The Work and the Gift. Chicago: University of Chicago Press.

Seeman, Melvin 1959. 'On The Meaning of Alienation'. American Sociological Review 24: 783-91.

- 1975. 'Alienation Studies'. Annual Review of Sociology 1: 91-123.

Snyder, M. and S. Gangestad 1986. 'On the Nature of Self-Monitoring: Matters of Assessment, Matters of Validity'. Journal of Personality and Social Psychology 51: 125-39.

Stalson, J. Owen 1942. Marketing Life Insurance: Its History in America. Cambridge, MA: Harvard University Press.

Stets, Jan E. and Teresa Tsushima 2001. 'Negative Emotion and Coping Responses Within Identity Control Theory'. Social Psychology Quarterly 64: 283-95.

- and Jonathan H. Turner 2006. Handbook of the Sociology of Emotions. New York: Springer Science + Business Media, LLC.

Sutton, Robert I. 1991. 'Maintaining Norms about Expressed Emotions'. Administrative Science Quarterly 36: 245-68.

Thoits, Peggy A. 1990. 'Emotional Deviance: Research Agendas'. In T. D. Kemper (ed) 
Research Agendas in the Sociology of Emotions. Albany: State University of New York Press: 180-203.

Turner, Jonathan H. and Jan E. Stets 2005. The Sociology of Emotions. New York: Cambridge University Press.

- 2006. 'Sociological Theories of Human Emotions'. Annual Review of Sociology 32: 25-52.

Weber, Max 1947. The Theory of Social and Economic Organization. London: W. Hodge. Wharton, A. S. 1993. 'The Affective Consequences of Service Work: Managing Emotions on the Job'. Work Occupations 20: 205-32.

Zapf, Dieter 2002. 'Emotion Work and Psychological Well-being: A Review of the Literature and Some Conceptual Consideration'. Human Resource Management Review 12: 237-68.

Zelizer, Viviana A. 1978. 'Human Values and the Market: The Case of Life Insurance and Death in 19th-Century America'. The American Journal of Sociology 84: 591-610.

- 1983. Morals and Markets: The Development of Life Insurance in the United States. New Brunswick, NJ: Transaction Books. 